\title{
PENDIDIKAN MULTIKULTURAL DALAM PERSFEKTIF PENDIDIKAN ISLAM
}

\author{
Mursal Aziz \\ Fakultas Ilmu Tarbiyah dan Keguruan Universitas Islam Negeri Sumatera Utara \\ Jl. Williem Iskandar Pasar V Medan Estate \\ mursalaziz7@gmail.com
}

\begin{abstract}
Abstrak: Allah swt. menciptakan manusia dengan perbedaan-perbedaan antara satu dengan yang lain, termasuk dalam budaya. Perbedaan-perbedaan tersebut dapat menyebabkan gesekan-gesekan yang menghasilkan konflik. Pendidikan adalah upaya dalam pemecahan masalah konflik, dengan pendidikan multikultural diharapkan setiap individu atau kelompok bisa menerima dan menghargai setiap perbedaan, hidup berdampingan dengan damai dan tenang walaupun berbedabeda. Sehingga terbentuk sebuah negara dan bangsa yang damai dan sejahtera sebagaimana yang menjadi tujuan pendidikan Islam.
\end{abstract}

Kata Kunci: Pendidikan, Multikultural dan Islam

\section{Pendahuluan}

Manusia diciptakan Allah swt. dengan sebaik-baik ciptaan dengan kasih sayang-Nya. Allah swt. menciptakan manusia dengan perbedaan-perbedaan antara satu dengan yang lain. Perbedaan-perbedaan tersebut tentunya memiliki arti dan makna, hal ini sesuai dengan yang diisyaratkan Allah swt. bahwa Dia tidak menciptakan langit, bumi dan apa yang diantara keduanya termasuk manusia secara main-main, kecuali dengan $a l-h a q,{ }^{1}$ begitu juga dengan perbedaanperbedaan yang ada pada manusia memiliki makna dan arti.

Perbedaan-perbedan yang terjadi pada diri manusia adalah hal yang wajar dan seharusnya dijadikan rahmat serta menambah keimanan kepada Allah swt. Diantara perbedaan-perbedaan yang ada pada manusia adalah perbedaan budaya dan suku yang sangat banyak dan beragam dalam berbagai negara. Hal tersebut tentunya harus menambah keimanan kepada Allah swt, karena dengan iradah-Nya menjadikan manusia berbeda-berbeda dalam berbudaya dan bernegara.

Indonesia merupakan salah satu negara multikultural terbesar di dunia, fakta ini dapat dilihat dari berbagai kondisi sosio-kultural maupun geografis Indonesia yang begitu beragam dan sangat luas, terbentang mulai pulau Sumatera, Jawa, Kalimantan, Sulawesi dan Papua yang diperkirakan sekitar 13.000 pulau

1 Al-Rasyidin, Falsafah Pendidikan Islami: Membangun Kerangka Ontologi, Epistimologi, dan aksiologi Praktik Pendidikan (Bandung: Citapustaka Media Perintis, 2012), h. 8. 
besar dan kecil, dengan penduduk lebih dari 200 ribu juta jiwa, terdiri dari sekitar 300 suku, 200 bahasa yang berbeda. ${ }^{2}$ Kondisi ini membuat Indonesia tercatat sebagai salah satu dari berbagai negara berkembang yang berpotensi dalam penyelenggaraan pendidikan multikultural untuk menjadi contoh dalam memajukan bangsa dan negara.

Pendidikan sebagai salah satu sarana strategis dalam upanya membangun jati diri bangsa yang religius dan damai bagi negara berkembang. Pendidikan yang tepat menjanjikan pembangunan bangsa dan negara dengan model pendidikan multikultural. Walaupun Indonesia menjadi contoh, bukan berarti pembahasan tentang pendidikan multikultural ini hanya terhenti pada Indonesia saja, akan tetapi universal untuk berbagai negara yang memiliki beragam budaya.

Pendidikan multikultural pada dasarnya tidak bertentangan dengan ajaran Islam, khususnya Alquran dan hadis yang menjadi sumber hukum ajaran agama Islam. Keanekaragaman yang ada justru menjadi kekayaan intelektual untuk dikaji dan dipelajari, sebagaimana beberapa ayat Alquran yang selalu mengingatkan dengan kalimat "afala ta'qilun, afala tatafakkarun, afala tatadabbarun dan kalimat-kalimat yang lain yang senada. Dengan pendidikan multikultural diharapkan setiap individu atau kelompok bisa menerima dan menghargai setiap perbedaan, hidup berdampingan dengan damai dan tenang. Dengan demikian dapat terbentuk sebuah negara dan bangsa yang damai dan sejahtera baldatun thayyibatun warabbun ghafur.

\section{Pendidikan Multikultural}

\section{Pengertian dan Konsep Pendidikan Multikultural}

Pengertian pendidikan menurut Marimba adalah bimbingan atau pimpinan secara sadar oleh pendidik terhadap perkembangan jasmani dan rohani peserta didik menuju kepribadian yang utama. $^{3}$ Sementara pengertian pendidikan multikultural menurut Andersen dan Cusher diartikan sebagai pendidikan mengenai keragaman budaya. ${ }^{4}$ Tilaar mengemukakan bahwa pendidikan

2 Abd. Rachman Assegaf, Filsafat Pendidikan Islam: Pradigma Baru Pendidikan Hadhari Berbasis Integratif-Interkoneksi (Jakarta: Rajawali Pers, 2014), h. 309.

3 Ahmad Tafsir, Ilmu Pendidikan dalam Perspektif Islam (Bandung: Remaja Rosda Karya, 2011), h. 24.

${ }^{4}$ Choirul Mahfud, Pendidikan Multikultural (Yogyakarta: Pustaka Pelajar, 2010), h. 175. 
multikultural adalah pendidikan untuk meningkatkan penghargaan terhadap etnik dan budaya masyarakat. ${ }^{5}$ Muhaemin el Ma'hady berpendapat bahwa secara sederhana pendidikan multikultural memiliki defenisi sebagai pendidikan tentang keragaman kebudayaan dalam meresponi perubahan demografis dan kultural lingkungan masyarakat tertentu atau bahkan dunia secara keseluruhan (global). ${ }^{6}$

Akar kata multikultural adalah kebudayaan. Secara etimologi multikultural dibentuk dari kata 'multi' yang berarti banyak, 'kultur' yang bermakna budaya.' Koentjaraningrat merumuskan sedikitnya ada tiga wujud kebudayaan, yaitu: 1) wujud ide, gagasan, nilai-nilai, norma dan peraturan, 2) wujud kelakuan berpola dari manusia dalam masyarakat, 3) wujud benda-benda hasil karya manusia. ${ }^{8}$ Berdasarkan hal ini penulis memberikan pengertian bahwa pendidikan multikultural hanya dalam konteks budaya, yaitu hasil cipta, rasa dan karsa manusia yang terlihat dari segala hasil karya manusia, dalam hal ini tidak termasuk ke dalam ranah agama secara universal. Agama kurang tepat untuk dimasukkan ke dalam ranah multikultural secara universal, karena konsep multikultralisme menekankan keanekaragaman kebudayaan dalam kesederajatan, ${ }^{9}$ sementara agama Islam pada hakikatnya tidak mungkin sederajat dengan agamaagama lain yang ada, karena agama di sisi Allah swt. adalah Islam, ${ }^{10}$ tetapi kalau yang dimaksud agama dipandang sama dalam hukum, hak dan kewajiban dalam bernegara hal itu tidak menjadi masalah.

Pendidikan multikultural adalah pendidikan yang mencakup seluruh siswa tanpa membedakan perbedaan kelompok-kelompok, seperti: gender, etnis, ras, budaya, bahasa, strata sosial, dan hal-hal lain termasuk berkebutuhan khusus. Dengan pendidikan multikultural diharapkan akan mempermudah tercapainya tujuan pendidikan dan kehidupan sosial yang damai, tidak membedakan antara suku maupun kasata. Perlakuan pendidik harus sama kepada peserta didik yang

\footnotetext{
${ }^{5}$ Haidar Putra Daulay, Pendidikan Islam: dalam Perspektif Filsafat (Jakarta: Kencana, 2014), h. 165.

${ }^{6}$ Mahfud, Pendidikan, h. 176.

${ }^{7}$ Ibid., h. 75. h. 142 .

${ }^{8}$ Fahrul Rizal, dkk., Humanika: IAD, IBD, ISD (Jakarta: Hijri Pustaka Utama, 2009),

9 Lihat Mahfud, Pendidikan, h. 95.

${ }^{10}$ QS. Ali Imran/3: 19.
} 
memiliki suku-suku atau budaya yang berbeda, jangan karena satu marga membuat perlakuan pendidik berbeda dengan peserta didik lainnya.

Konsep pedidikan multikultural perlu secara terus-menerus dikembangkan untuk disampaikan melalui berbagai forum atau media. Hal tersebut bertujuan untuk menumbuhkan kesadaran dalam diri setiap orang untuk hidup dalam sebuah bangsa yang mempunyai keragaman budaya, pada akhirnya bisa saling menghargai dan menghormati dalam setiap perbedaan.

\section{Pendidikan Multikultural dalam Islam}

Islam adalah agama fitrah dan universal yang menjunjung tinggi nilai-nilai sosial, persamaan hak dan mengakui adanya keragaman latar belakang budaya dan kemajemukan. Multikultural menurut Islam adalah sebuah sunnatullah yang tidak akan berubah, juga tidak mungkin dilawan atau diingkari, karena Allah swt. menciptakan manusia berbeda-beda. Tidak ada perbedaan antara satu bangsa dengan bangsa yang lain, satu suku dengan suku yang lain, dan tidak ada perbedaan antara satu orang dengan orang yang lain kecuali dalam hal memelihara hak dan kewajiban. ${ }^{11}$

Agama Islam datang membawa kedamaian di setiap sisi dan lini kehidupan. Sebelum pendidikan multikultural diperkenalkan pendidikan Barat, jauh sebelumnya itu Islam sudah menerapkan konsep pendidikan multikultural sejak Islam berkembang memajukan kehidupan umat. Islam hadir untuk pertama kalinya di daerah Arab yang memiliki banyak kafilah, suku (bani) yang saling bertentangan dan bahkan saling berperang karena hal yang sebetulnya sepele. Akan tetapi, ketika ajaran Islam hadir, maka pertikaian dan pertentangan ini dapat dihindari dengan pedoman dan acuan Alquran dan hadis yang tidak membedakan antara satu kaum dengan kaum lainnya. Berkaitan hal tersebut Allah swt. berfirman, yaitu:

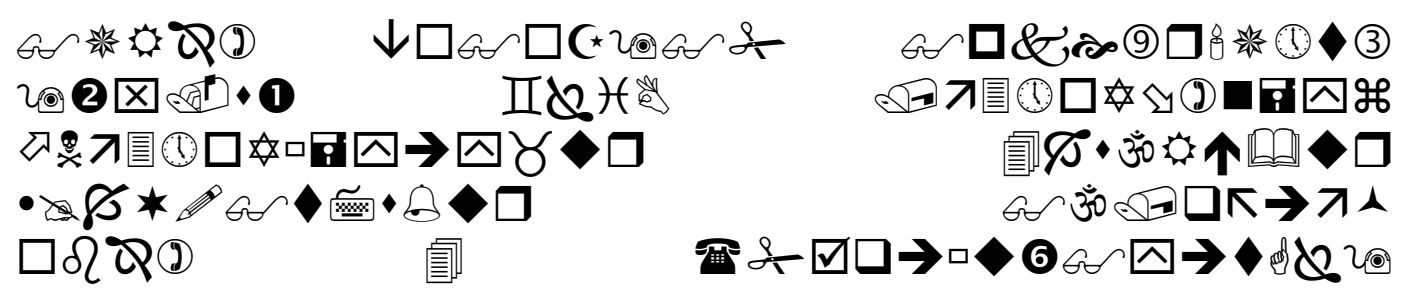

11 Abbas Muhammad Al-Aqqad, Filsafat Qur'an: Filsafat Spritual dan Sosial dalam Isyarat Qur'an (Jakarta: Pustaka Firdaus, 1986), h. 55. 


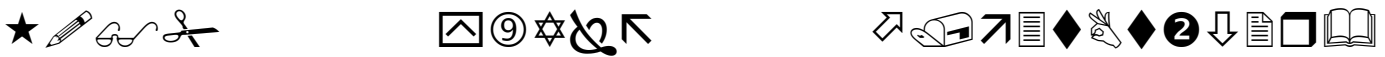 ע: \\ $12<32$ 娄田}

Hai manusia, Sesungguhnya kami menciptakan kamu dari seorang lakilaki dan seorang perempuan dan menjadikan kamu berbangsa-bangsa dan bersuku-suku supaya kamu saling kenal-mengenal. Sesungguhnya orang yang paling mulia diantara kamu disisi Allah ialah orang yang paling taqwa diantara kamu. Sesungguhnya Allah Maha mengetahui lagi Maha Mengenal.

Asbab Nuzul ayat di atas adalah bahwa pada peristiwa Fathu Makkah, Bilal naik ke atas ka'bah lalu adzan. Banyak yang merespon negatif, termasuk 'Attab bin Usaid, Suhail bin Amar dan termasuk Al Harits bin Hisyam berkata: Muhammad tidak menemukan selain burung gagak yang hitam ini untuk dijadikan mu'adzin. Maka Jibril datang kepada Nabi Muhammad saw. dan memberitahukan kepada beliau apa yang mereka katakan dan merekapun mengaku. Maka Allah swt. menurunkan ayat ini sebagai cegahan bagi mereka yang membanggakan nasab dan Allah swt. menerangkan bahwa keutamaan itu terletak pada takwa. ${ }^{13}$

Kata 'Syu'uban' adalah bentuk jamak yang artinya tingkat nasab keturunan yang paling tinggi. ${ }^{14}$ Ayat ini juga menegaskan kesatuan asal usul manusia dengan menunjukkan kesamaan derajat manusia. Tidak wajar seseorang atau kelompok berbangga dan merasa lebih tinggi dari yang lain, bukan saja antar satu bangsa, suku, warna kulit begitu juga dengan jenis kelamin dan lainnya. ${ }^{15}$

Ayat di atas menegaskan bahwa Allah swt. menciptakan manusia dari asal yang sama, kemudian dijadikan dalam kelompok syu'ub dan qabail. Seluruh manusia setara dalam kemuliaan sebagai keturunan Adam dan Hawa yang tercipta dari tanah. Mereka menjadi lebih mulia daripada yang lain hanya berdasar tingkat ketaqwaannya, sebatas mana ketaatan kepada Allah swt. dan rasul-Nya. Sedangkan tujuan penciptaan semacam itu ialah agar masing-masing saling kenalmengenal.

${ }^{12}$ QS. Al-Hujurat/49: 13.

13 Ahmad Musthafa Al Maraghi, Tafsir Al-Maraghi (Semarang: Toha Putra, 1989), h. 239.

${ }^{14}$ Imam Jalaluddin Al Mahalli dan Imam Jalaluddin As-Suyuti, Tafsir Jalalain Jilid 4 (Bandung: Sinar Baru Algesindo , 2015), h.2238.

${ }_{15}$ M. Quraish Shihab, Tafsir Al-Misbah: Pesan, Kesan dan Keserasian al-Qur'an (Jakarta: Lentera Hati, 2009), h. 616-617. 
Berdasarkan uraian di atas, maka pendidikan multikultural tidak bertentangan dengan ajaran Islam, bahkan sebagaimana yang telah disebutkan diawal bahawa Islam lebih awal mengajarkan dan mengenalkan pendidikan multikultural tersebut dibandingkan dengan yang lain. Alquran sebagai sumber hukum agama Islam menjadi bukti bahwa Islam adalah agama yang damai dan tidak-membeda-bedakan suatu kaum dengan kaum yang lain. Keanekaragaman yang ada justru menjadi kekayaan intelektual untuk dikaji, sebagaimana beberapa ayat Alquran yang menjelaskan hal tersebut. Bukan itu saja, bahkan hadis Rasulullah saw. juga banyak yang senada dengan hal tersebut seperti hadis yang masyhur yaitu: Tidak ada perbedaan bangsa Arab dengan bangsa lainnya dan tidak ada perbedaan kulit putih dengan kulit hitam kecuali taqwa.

Bukti Islam adalah mendukung dalam pendidikan multikultural dapat dilihat dari pelaksanaan ibadah haji yang dilakukan umat Islam di baitullah. Ketika umat Islam melaksanakan ibadah haji, apapun propesinya, jabatannya, sukunya bahkan negaranya, semua memakai pakaian ihram berwarna sama yaitu putih, hal ini menunjukkan bahwa Islam tidak membedakan antara suku maupun bangsa secara global.

\section{Wacana Pendidikan Multikultural dalam Pendidikan Global}

Pendidikan merupakan bagian dari kebudayaan dan tidak dapat dipisahkan dari kebudayaan. Sebab manusia pada hakikatnya adalah makhluk sosial yang pada hakikatnya pasti melakukan interaksi dengan orang lain. Pendidikan mewarnai setiap gerak dan langkah peradaban manusia yang merupakan jalan untuk memberikan warna bagi jalan kehidupan manusia. ${ }^{16}$

Pendidikan merupakan usaha untuk mengembangkan potensi individu apabila ditinjau dari sudut pandang individu, sebaliknya dari sudut pandang kemasyarakatan, pendidikan adalah sebagai pewarisan nilai-nilai budaya. Manusia sebagai makhluk berbudaya adalah pencipta budaya itu sendiri dan kemudian meningkat sejalan dengan peningkatan potensi manusia pencipta budaya itu.

\footnotetext{
${ }^{16}$ Syafaruddin, dkk., Sosiologi Pendidikan (Medan: Perdana Publishing, 2016), h. 171.
} 
Kebudayaan suatu masyarakat atau bangsa sangat ditentukan oleh kualitas sumber daya manusia yang menjadi pendukung nilai-nilai budaya tersebut. ${ }^{17}$

Globalisasi telah membawa nilai-nilai baru yang berbeda dengan dengan nilai-nilai budaya masyarakat pada era sebelumnya. Untuk dapat eksis dan berperan maka setiap masyarakat dan bangsa harus mentransformasikan nilai-nilai baru tersebut. Di sinilah peran strategis dunia pendidikan dalam mempersiapkan dalam konteksnya menyikapi berbagai perubahan global yang terjadi. ${ }^{18}$

Aktivitas pendidikan menjadikan peserta didik sebagai sasaran (objek) dan sekaligus sebagai subjek pendidikan secara global. Oleh karena itu, dalam memahami hakikat pendidikan perlu dilengkapi pemahaman tentang ciri-ciri umum peserta didik untuk membantu lancarnya konsep pendidikan multikultural yang dicanangkan. Setidaknya, secara umum peserta didik memiliki lima ciri, yaitu:

a. Peserta didik sedang dalam keadaan berdaya untuk menggunakan kemampuan, kemauan, dan sebagainya, maka pendidik harus mengembangkannya.

b. Mempunyai keinginan untuk berkembang kearah dewasa, oleh sebab itu pendidik harus memfasilitasinya.

c. Peserta didik mempunyai latar belakang yang berbeda-beda, peserta didik harus diajarkan untuk saling menghargai sesamanya.

d. Peserta didik melakukan penjelajahan terhadap alam sekitarnya dengan potensi-potensi dasar yang dimiliki secara individual. ${ }^{19}$

Merancang pendidikan dalam tatanan masyarakat yang penuh dengan permasalahan antar kelompok seperti di Indonesia atau berbagai negara lain memang tidaklah mudah. Hal ini bertambah sulit jika tatanan masyarakat yang ada masih penuh diskriminasi dan bersifat rasis. Keadaan ini dirasakan oleh umat Islam Rohingnya yang berada di Miyanmar, di era globalisasi ini mereka masih sulit merdeka dari diskriminasi oleh masyarakat mayoritas. Berbeda pula dengan

17 Jalaluddin dan abdullah Idi, Filsafat Pendidikan: Manusia, Filsafat dan Pendidikan (Jogjakarta: Ar-Ruzz Media, 2007), h. 195.

18 Al Rasyidin, Percikan Pendidikan: Dari Filsafat Hingga Praktik Pendidikan (Bandung: Citapustaka Media Perintis, 2009), h. 204.

${ }^{19}$ Lihat Mahfud, Pendidikan, h. 178. 
di Indonesia, Indonesia sangat toleran dan saling hidup bersama, tetapi masyarakat atau oknum minoritas berbuat semena-mena dengan sikap yang toleransi, seperti kasus ahok menggemparkan masyarakat Indonesia. Apabila dilihat dari sejarah, bangsa Arab yang memiliki banyak suku (bani) juga tidak terlepas dari pertikaian antar kelompok, saling perang dan serang sampai agama Islam datang mempersatukan perbedaan-perbedaan.

Dalam kondisi seperti ini, pendidikan multikultural diarahkan sebagai upaya bantuan atau advokasi untuk menciptakan masyarakat yang toleran. Adapun untuk mencapai sasaran tersebut, diperlukan sejumlah pendekatan. Adapun beberapa pendekatan dalam pendidikan multikultural tersebut adalah sebagai berikut:

1. Tidak lagi menyamakan pandangan pendidikan dengan persekolahan, atau pendidikan multikultural dengan program-program sekolah formal.

2. Menghindari pandangan yang menyamakan kebudayaan dengan kelompok etnik.

3. Mempertahankan dan memperluas solidaritas kelompok akan menghambat sosialisasi kedalam kebudayaan baru. Pendidikan multikultural bagi pluralisme budaya dan pendidikan multikultural tidak dapat disamakan dengan logis.

4. Pendidikan multikultural meningkatkan kompetensi dalam beberapa kebudayaan. Kebudayaan mana yang akan diadopsi, itu ditentukan oleh situasi dan kondisi secara proporsional.

5. Kemungkinan bahwa pendidikan meningkatkan kesadaran tentang kompetensi dalam beberapa kebudayaan. ${ }^{20}$

Dalam persfektif filsafat pendidikan Islam, proses saling belajar yang dapat berlaku dari berbagai lingkungan, baik lingkungan keluarga, sekolah dan lingkungan masyarakat, merupakan perjalanan kebudayaan manusia dalam mencerdaskan dirinya, memahami keinginan manusia yang beragam. ${ }^{21}$

\footnotetext{
${ }^{20}$ Mahfud, Pendidikan, h. 191-193.

${ }^{21}$ Hasan Basri, Filsafat Pendidikan Islam (Bandung: Pustaka Setia, 2009), h. 48.
} 
Pendidikan multikultural menurut James Bank memiliki beberapa dimensi yang saling berkaitan satu dengan yang lain yang harus dipertimbangkan. Adapun dimensi tersebut yaitu:

a. Content Integration, yaitu mengintegrasikan berbagai budaya dan kelompok untuk mengilustrasikan konsep dasar, generalisasi, dan teori dalam mata pelajaran atau disiplin ilmu, seperti mata pelajaran Pendidikan Kewarganegaraan (PKn).

b. The knowledge construction process, yaitu membawa siswa untuk memahami implikasi budaya ke dalam sebuah mata pelajaran, termasuk dalam pelajaran sejarah atau IPS.

c. An equity paedagogy, yaitu menyesuaikan metode pengajaran dengan cara belajar siswa dalam rangka memfasilitasi prestasi akademik siswa yang beragam baik dari segi ras, budaya, ataupun sosial. Peserta didik akan lebih memahami materi pembelajaran apabila dikaitkan dengan keadaan budaya yang dialami peserta didik dalam kehidupannya sehari-hari.

d. Prejudice reduction, yaitu mengidentifikasi karakteristik ras siswa dan menentukan metode pengajaran mereka. Kemudian, melatih kelompok untuk berpartisipasi dalam kegiatan olahraga, berinteraksi dengan seluruh staff dan siswa yang berbeda etnis dan ras dalam upaya menciptakan budaya akademik yang toleran dan inklusif. ${ }^{22}$

Pendidikan multikultural merupakan ide, upaya pergerakan pembaharuan pendidikan dan proses pendidikan yang tujuan utamanya adalah untuk mengubah struktur lembaga pendidikan supaya peserta didik baik laki-laki maupun perempuan, peserta didik yang berkebutuhan khusus, dan peserta didik yang merupakan anggota dari kelompok ras, etnis, dan kultur yang bermacam macam itu akan memiliki kesempatan yang sama untuk mencapai prestasi akademis di dalam pendidikannya. Sehingga dengan demikian pendidik tidak akan membedabedakan budaya, suku peserta didik dan tidak ditemui lagi pendidik yang memberikan nilai tinggi kepada peserta didik disebabkan memiliki marga yang sama dengannya. Dengan berjalannya pendidikan multikultural ini dengan baik

\footnotetext{
${ }^{22}$ Mahfud, Pendidikan, h. 177-178.
} 
diharapkan tercapainya tujuan pendidikan sehingga terjadi kedamaian secara global.

\section{Urgensi Pendidikan Multikultural}

Pendidikan multikultural apabila ditinjau dari sisi filsafat maka pendidikan multikultural termasuk ke dalam filsafat praktis (hikmah 'amaliyah). Hal tersebut karena filsafat praktis adalah filsafat yang membahas perilaku manusia sebagaimana seharusnya. ${ }^{23}$ Hal ini dikarena pendidikan multikultural mengkaji tentang perbedaan-perbedaan yang terdapat pada manusia.

Pendidikan berbasis multikulturalisme atau Multicultural Based Education muncul sebagai sebuah disiplin ilmu pada dekade 1960-an dan 1970-an. ${ }^{24}$ Krisis multidimensi yang terjadi di Indonesia dan berbagai negara lain harus diakui telah menyebabkan berbagai persoalan sosial yang semakin meluas dan menjadi-jadi. Akibat dari keadaan yang demikian menyebabkan orang yang paling menderita adalah masyarakat yang berada paling bawah atau minoritas. Oleh sebab itu, dalam pendidikan multikultural ditekankan adanya pembangunan sikap (afektif) yang termasuk di dalamnya adalah bagaimana membangun kesadaran, pemahaman yang kritis siswa terhadap berbagai penomena sosial yang bersentuhan langsung dengan kepentingan masyarakat umum. ${ }^{25}$

Pendidikan multikultural sangat penting dalam dunia pendidikan maupun kehidupan bermasyarakat. Adapun urgensi pendidikan multikultural adalah sebagai berikut:

\section{a. Sebagai Sarana Alternatif Pemecahan Konflik}

Hampir semua masyarakat di dunia baik yang amat sederhana maupun yang amat kompleks sifatnya, dalam pergaulan antar individu ada perbedaan kedudukan dan derajat (status). ${ }^{26}$ Pendidikan Multikultural pada awalnya bertujuan agar populasi mayoritas dapat bersikap toleran terhadap minoritas. Studi

23 Al Rasyidin dan Ja'far, Filsafat Ilmu: Dalam Tradisi Islam (Medan: Perdana Publishing, 2015), h. 46.

${ }^{24}$ Mahfud, Pendidikan, h. 196.

25 M. Ainul Yaqin, Pendidikan Multikultural: Cross-Cultural Understanding untuk Demokrasi dan Keadilan (Yogyakarta: Pilar Media, 2007), h. 144

${ }^{26}$ Koentjaraningrat, Beberap Pokok Antropologi Sosial (Jogjakarta: Dian Rakyat, 1985), h. 174 . 
ini juga mempunyai tujuan politis sebagai alat kontrol sosial penguasa terhadap warganya, agar kondisi negara aman dan stabil. ${ }^{27}$

Semua problem sosial bersumber dari pertentangan yang terus menerus antara kecenderungan individual yang dikuasai oleh nalurinya dan kehendak merealisasikannya. ${ }^{28}$ Dalam hubungan sosial antar kelompok, seseorang sering kali memiliki sikap negatif terhadap anggota kelompok lain yang sering tidak didasarkan pada evaluasi dalam kapasitasnya sebagai individu, tetapi sebagai anggota kelompoknya. ${ }^{29}$

Munculnya konflik horisontal yang diwarnai sara sebagaimana yang terjadi di daerah Ambon, Poso, Sampit dan daerah-daerah lain merupakan cermin dari ketidak utuhan pemaknaan dari Bhineka Tunggal Ika. ${ }^{30}$ Berdasarkan konflikkonflik yang terjadi maka keberadaan pendidikan multikultural sangat diperlukan. Pendidikan multikultural adalah strategi pendidikan yang diterapkan pada semua jenis mata pelajaran dengan cara menggunakan perbedaan-perbedaan kultural yang ada pada diri siswa seperti perbedaan etnis, agama, bahasa, gender, kelas sosial, ras, kemampuan, dan umur agar proses belajar menjadi lebih efektif dan mudah.

Penyelenggaraan pendidikan multikultural di dunia pendidikan diyakini dapat menjadi solusi nyata konflik yang terjadi di masyarakat, dengan demikian akan dapat menjadi sarana alternatif pemecahan konflik sosial-budaya. ${ }^{31}$ Modelmodel pembelajaran mengenai kebangsaan memang sudah dirintis, seperti pendidikan pancasila, kewarganegaraan dan lain-lain. Namun demikian, hal itu perlu tambahan upaya supaya menghasilkan lulusan yang dapat mengahargai perbedaan masing-masing suku, budaya maupun etnis. Perubahan yang diharapkan melalu pendidikan adalah terciptanya kondisi yang damai, nyaman, toleran dalam kehidupan masyarakat, dan tidak selalu muncul konflik yang disebabkan oleh perbedaan budaya.

\section{b. Supaya Tidak Tercerabut dari Akar Budaya}

\footnotetext{
${ }^{27}$ Yaqin, Pendidikan, h. 23.

${ }^{28}$ Nadim Al Jisr, Filsafat Kebebasan dalam Islam (Solo: Pustaka Mantiq, 1991), h. 23.

${ }^{29}$ Ibnu Hadjar, Prasangka Keagamaan (Semarang: Wali Songo Press, 2010), h. 18.

${ }^{30}$ Bedjo Sujanto, Pemahaman Kembali Makna Bhineka Tunggal Ika: Dalam Kehidupan Masyarakat, Berbangsa dan Bernegara (Jakarta: Sagung Seto, 2007), h.28.

${ }^{31}$ Mahfud, Pendidikan, h. 216.
} 
Filsafat pendidikan Al-Attas sangat jelas menekankan pengembangan individu, tetapi hal ini tidak dapat dipisahkan secara sosial dalam hal cara dan konteks pelaksanaannya. ${ }^{32}$ Pendidikan multikultural adalah salah satu pendekatan dalam pendidikan yang menekankan perlunya siswa mengenal dan menghargai budaya yang berbeda dari budaya asal mereka. Dalam hal ini siswa bukan saja diperkenalkan berbagai budaya yang ada di dunia, tetapi siswa juga diajak untuk merasa bangga pada budaya sendiri dan menghargai budaya orang lain. ${ }^{33}$

Dede Rosyada mengemukakan tiga hal dalam pengertian pendidikan multikultural, yaitu: 1) Pendidikan keragaman budaya dalam masyarakat; 2) pendidikan yang menawarkan ragam model dalam keragaman budaya dalam masyarakat; 3) pendidikan yang membentuk sikap siswa untuk menghargai keberagaman budaya dalam masyarakat. ${ }^{34}$ Tujuan akhir pendidikan multikultural peserta didik tidak hanya mampu memehami dan menguasai materi pelajaran yang dipelajarinya akan tetapi diharapkan juga bahwa peserta didik akan mempunyai karakter yang kuat untuk selalu bersikap demokratis, pluralis dan humanis. ${ }^{35}$

Pendidikan multikultural diharapkan mampu membangun bangsa yang sesuai dengan kondisi masyarakat bangsa yang beragam. Dengan keaneka ragaman budaya diharapkan peserta didik diharapkan mampu untuk merasa bangga dengan budaya yang dimilikinya dan sekaligus bisa menghargai budaya orang lain yang berbeda dengannya. Salah satu contoh uregen hal ini adalah keanekaragaman budaya dan ras yang ada di Indonesia yang merupakan sebuah kekayaan yang harus dijaga dan lestarikan, jangan sampai peserta didik tergerus dengan budaya asing yang dilihatnya pada era globalisasi yang serba canggih.

\section{c. Sebagai Landasan Pengembangan Kurikulum Nasional}

Kurikulum pendidikan islami meliputi seluruh kawasan kehidupan seorang Muslim baik dalam kekhalifahan maupun pengabdiannya kepada Allah swt.

\footnotetext{
${ }^{32}$ Wan Mohd Nor Wan Daud, Filsafat dan Praktik Pendidikan Islam: Syed M. Naquib AlAttas (Bandung: Mizan, 2003), h.189.

${ }^{33}$ Assegaf, Filsafat, h. 310.

${ }^{34}$ Daulay, Pendidikan h. 164-165.

${ }^{35}$ Yaqin, Pendidikan, h. 26.
} 
sebagai makhluk ibadah. ${ }^{36}$ Pengembangan kurikulum yang berdasarkan pendidikan multikultural dapat dilakukan berdasarkan langkah-langkah berikut:

1) Mengubah filosofi kurikulum dari yang berlaku secara serentak seperti sekarang menjadi filosofi pendidikan yang sesuai dengan tujuan, misi, dan fungsi setiap jenjang pendidikan dan unit pendidikan.

2) Harus merubah teori tentang konten (curriculum content) yang mengartikannya sebagai aspek substantif yang berisi fakta, teori, generalisasi, menuju pengertian yang mencakup nilai moral, prosedur, proses, dan keterampilan (skills) yang harus dimiliki generasi muda.

3) Teori belajar yang digunakan harus memperhatikan unsur keragaman sosial, budaya, ekonomi, dan politik.

4) Proses belajar yang dikembangkan harus berdasarkan cara belajar berkelompok dan bersaing secara kelompok dalam situasi yang positif. Dengan cara tersebut, perbedaan antarindividu dapat dikembangkan sebagai suatu kekuatan kelompok dan siswa terbiasa untuk hidup dengan keberanekaragaman budaya.

5) Evaluasi yang digunakan harus meliputi keseluruhan aspek kemampuan dan kepribadian peserta didik sesuai dengan tujuan dan konten yang dikembangkan. ${ }^{37}$

Pendidikan multikultural memang sebuah konsep yang dibuat dengan tujuan untuk menciptakan persamaan peluang pendidikan bagi semua siswa yang berbeda-beda ras, etnis, kelas sosial dan kelompok budaya. Diantara tujuan penting dari konsep pendidikan multikultural adalah untuk membantu semua siswa agar dapat memperoleh pengetahuan, sikap dan ketrampilan yang diperlukan dalam menjalankan peran-peran sebaik mungkin pada lingkungan masyarakat serta diperlukan untuk berinteraksi, negosiasi, dan komunikasi dengan warga dari kelompok beragam agar tercipta sebuah tatanan masyarakat bermoral yang berjalan untuk kebaikan bersama.

\section{d. Menuju Masyarakat yang Multikultural}

\footnotetext{
${ }^{36}$ Al-Rasyidin, Falsafah, h. 162-163.

${ }^{37}$ Mahfud, Pendidikan, h. 222-224.
} 
Pendidikan multikultural melatih dan membangun karakter siswa agar mampu bersikap demokratis, humanis dan pluralis dalam lingkungan mereka. ${ }^{38}$ Inti dari cita-cita sebuah negara adalah mewujudkan masyarakat yang demokratis, dan ditegakkan hukum untuk supremasi keadilan, pemerintah yang bersih dari KKN, terwujudnya keteraturan sosial serta rasa aman dalam masyarakat yang menjamin kelancaran produktivitas warga masyarakat, dan kehidupan ekonomi yang mensejahterakan rakyat.

Sebagaimana yang telah diamati Tariq Madood, tujuan dari multikulturalisme demokratis bukan untuk mengusir para aktor atau wacana religius dari ruang lingkup publik, melainkan untuk mengusahakan dimasukkannya kelompok-kelompok yang marjinal dan tidak diuntungkan, termasuk komunitas-komunitas religius ke dalam kehidupan publik. ${ }^{39}$ Berbagai konsep yang relevan dengan multikulturalisme antara lain adalah demokrasi, keadilan dan hukum, nilai-nilai budaya dan etos, kebersamaan dalam perbedaan yang sederajat, suku bangsa, kesukubangsaan, kebudayaan suku bangsa, keyakinan keagamaan, ungkapan-ungkapan budaya, domain privat dan publik, HAM, hak budaya komuniti, dan kosnep-konsep lain yang relevan.

\section{Kesimpulan}

Pendidikan multikultural adalah pendidikan yang mencakup seluruh siswa tanpa membedakan perbedaan-perbedaan kelompok, seperti: gender, etnis, ras, budaya, bahasa, strata sosial, dan hal-hal lain termasuk berkebutuhan khusus. Dengan pendidikan multikultural diharapkan akan mempermudah tercapainya tujuan pendidikan dan kehidupan sosial yang damai, tidak membedakan antara suku maupun kasata. Perlakuan pendidik harus sama dan adil kepada peserta didik yang memiliki suku-suku atau budaya yang berbeda.

Pendidikan multikultural didasarkan pada keadilan sosial dan persamaan hak dalam memperoleh pendidikan. Islam tidak membeda-bedakan suku, etnis dan ras sebagaimana yang ditegaskan Alquran dan hadis Rasulullah saw. Oleh karena itu, pendidikan multikultural tidak bertentangan dengan ajaran Islam dan bahkan

${ }^{38}$ Yaqin, Pendidikan h. 25.

39 Robert W. Hefner, Politik Multikulturalisme: Menggugat Realitas Kebangsaan (Yogyakarta: Kanisius, 2007), h. 68. 
Islam lebih dahulu memberikan gagasan dan pedoman dalam pendidikan multikultural.

Dengan pendidikan multikultural diharapkan setiap individu atau kelompok bisa menerima dan menghargai setiap perbedaan, hidup berdampingan dengan damai dan tenang walaupun berbeda-beda. Sehingga terbentuk sebuah negara dan bangsa yang damai dan sejahtera sebagaimana yang menjadi tujuan pendidikan Islam.

\section{Pustaka Acuan}

Al Jisr, Nadim, Filsafat Kebebasan dalam Islam, Solo: Pustaka Mantiq, 1991.

Al Mahalli, Imam Jalaluddin dan Imam Jalaluddin As-Suyuti, Tafsir Jalalain Jilid 4, Bandung: Sinar Baru Algesindo, 2015.

Al Maraghi, Ahmad Musthafa, Tafsir Al-Maraghi, Semarang: Toha Putra, 1989.

Al Rasyidin dan Ja'far, Filsafat Ilmu: Dalam Tradisi Islam, Medan: Perdana Publishing, 2015.

Al Rasyidin, Falsafah Pendidikan Islami: Membangun Kerangka Ontologi, Epistimologi, dan aksiologi Praktik Pendidikan, Bandung: Citapustaka Media Perintis, 2012.

Al Rasyidin, Percikan Pendidikan: Dari Filsafat Hingga Praktik Pendidikan, Bandung: Citapustaka Media Perintis, 2009.

Al-Aqqad, Abbas Muhammad, Filsafat Qur'an: Filsafat Spritual dan Sosial dalam Isyarat Qur'an, Jakarta: Pustaka Firdaus, 1986.

Assegaf, Abd. Rachman, Filsafat Pendidikan Islam: Pradigma Baru Pendidikan Hadhari Berbasis Integratif-Interkoneksi, Jakarta: Rajawali Pers, 2014.

Basri, Hasan, Filsafat Pendidikan Islam, Bandung: Pustaka Setia, 2009.

Daud, Wan Mohd Nor Wan, Filsafat dan Praktik Pendidikan Islam: Syed M. Naquib Al-Attas, Bandung: Mizan, 2003.

Daulay, Haidar Putra, Pendidikan Islam: dalam Perspektif Filsafat, Jakarta: Kencana, 2014.

Hadjar, Ibnu, Prasangka Keagamaan, Semarang: Wali Songo Press, 2010.

Hefner, Robert W., Politik Multikulturalisme: Menggugat Realitas Kebangsaan, Yogyakarta: Kanisius, 2007. 
Jalaluddin dan abdullah Idi, Filsafat Pendidikan: Manusia, Filsafat dan Pendidikan, Jogjakarta: Ar-Ruzz Media, 2007.

Koentjaraningrat, Beberap Pokok Antropologi Sosial, Jogjakarta: Dian Rakyat, 1985.

Mahfud, Choirul, Pendidikan Multikultural, Yogyakarta: Pustaka Pelajar, 2010.

Rizal, Fahrul, dkk., Humanika: IAD, IBD, ISD, Jakarta: Hijri Pustaka Utama, 2009.

Shihab, M. Quraish, Tafsir Al-Misbah: Pesan, Kesan dan Keserasian al-Qur'an, Jakarta: Lentera Hati, 2009.

Sujanto, Bedjo, Pemahaman Kembali Makna Bhineka Tunggal Ika: Dalam Kehidupan Masyarakat, Berbangsa dan Bernegara, Jakarta: Sagung Seto, 2007.

Syafaruddin, dkk., Sosiologi Pendidikan, Medan: Perdana Publishing, 2016.

Tafsir, Ahmad, Ilmu Pendidikan dalam Perspektif Islam, Bandung: Remaja Rosda Karya, 2011.

Yaqin, M. Ainul, Pendidikan Multikultural: Cross-Cultural Understanding untuk Demokrasi dan Keadilan, Yogyakarta: Pilar Media, 2007. 